\title{
Micro-project Design of STEAM Education for Preschoolers Based on Striking Life Phenomena
}

\author{
Duhong Peng \\ School of Education, Suzhou University of Science and Technology, Suzhou, China
}

\section{Email address:}

pengduhong@126.com

\section{To cite this article:}

Duhong Peng. Micro-project Design of Steam Education for Preschoolers Based on Striking Life Phenomena. Education Journal. Special Issue: Pathway to Quality Preschool Education: Chinese Perspectives. Vol. 9, No. 3, 2020, pp. 59-63. doi: 10.11648/j.edu.20200903.11

Received: April 20, 2020; Accepted: May 6, 2020; Published: May 27, 2020

\begin{abstract}
As STEAM education has received growing attention in early childhood in recent years, how can we provide young children quality experience of STEAM learning? High-quality STEAM education project resources are a solid foundation for STEAM education quality assurance. The article takes striking phenomena in children's lives as a key point to extract and design micro-projects for STEAM education for young children. The main ideas behind the micro-projects design are as following: (1) Effectively capturing the striking life phenomena that can evoke a strong experience of children. (2) Extracting the key scientific problem and inferring progressive problems behind the phenomena. (3) Defining the micro-project and clarifying the composition of its sub-projects. (4) Realizing the integral elements of STEAM learning, etc. In a word, the micro-project design aims to establish interdisciplinary connections through in-depth exploration based on striking life phenomena and real problems. Taking the fingerprint of preschooler's fingertips as an example, behind the striking phenomena the key scientific question "What is the genetic secret (e.g., the genetic mechanisms)" can be extracted, and then a series of progressive questions like "What is the fingerprint? Is there any difference in fingerprints among children?" "Is the child's fingerprint the same as that of his/her parents?", "Does the child look the same as his/her parents?" "How can fingerprint be applied into our lives" can be drawn. To establish and clarify the micro-project and sub-projects based on these questions, and then to define embedded STEAM learning elements and other information. This is the design process and the main composition of a micro-project. These could be an effective way to boost quality project resource exploration for young children's STEAM education. Issues for further exploration are also discussed.
\end{abstract}

Keywords: Preschool STEAM Education, Striking Life Phenomenon, Micro-project Design

\section{Introduction}

STEAM (Science, Technology, Engineering, Art, and Mathematics education) is an educational concept of interdisciplinary integration of science, technology, engineering, art, mathematics, etc.; it aims to train compound talents who are good at questioning and innovative. [1] Though STEAM education is acting as one of the biggest educational reform and an important strategy for scientific and technological competition globally, researches primarily focus on the middle and high school levels. That is to say, research on STEAM education for young children is relatively limited at present, $[2,3]$; the theoretical and practical research of preschool STEAM in China is much scarce. [4, 5] The preschool children are full of curiosity about the world. They have 100,000 whys in their minds. They are rich in imagination and creativity. In particular, STEAM, which incorporates artistic elements, naturally fits children's curiosity and creativity. The preschool period is considered to be a sensitive period for the development of individual STEAM interests, so how to provide quality STEAM education for preschool children? How to design STEAM educational activities according to the characteristics of preschool children? The specific implementation of STEAM education is both the focus of research and the difficulties in practice. [6] In particular, China has not yet introduced relevant preschool STEAM education policies or content standards; at the same time, there is a lack of preschool STEAM education quality projects and sample references, and there is no lack of confusion and confusion in the practice of STEAM education in garden institutions. For example, there are problems such as unclear conceptual understanding, lack 
of clear positioning, blind copying, mechanical imitation, toyization, superficiality, new alienation, or paying too much attention to scientific knowledge and neglect the cultivation of children's ability to solve simple problems. [7, 8, 9] These STEAM education implementation issues reflect that STEAM education is a field full of opportunities and challenges. Therefore, focusing on the quality of preschool STEAM education practice in China, it is very important to cut into research from the specific implementation of project activity design. For example, some scholar has proposed ways in which preschool STEAM education can learn from projects,[4] some scholar has proposed a micro-education model based on the striking phenomena in children's lives. [10] Therefore this article intends to focus on the need for STEAM education at the early childhood level, using the concept of project learning to develop micro-project based on striking life phenomena, thereby providing practical ideas and reference framework for preschool STEAM education and quality projects design in future.

\section{The Entire Conception of STEAM Micro-project Design}

\subsection{The Necessity of Preschool STEAM Education Based on Striking Life Phenomena}

Preschool children are in the development stage from pre-computational thinking to specific computational thinking. They tend to focus on the external attributes of things and phenomena. At the same time, limited by the development of attention, they need wonderful and interesting, highlighting typical life phenomena in order to attract continuous attention and Reduce its cognitive load. Therefore, the preschool STEAM education project activities must closely integrate the children's physical and mental development laws, learning psychology and cognitive development characteristics of this age group, and create a wonderful and interesting learning situation that induces children's thinking through the intervention of intuitive, real and distinctive phenomena. Phenomenon-based method (Phenomenon-based Method) as a teaching concept first appeared in the 2014 Finnish curriculum standards; and in 2016 from the concept was implemented in practice. Phenomenon teaching is a teaching method based on a certain phenomenon, theme or topic, combining multiple disciplines. [11] The original intention of STEAM education is to promote the full integration of interdisciplinary through real problems. For young children, the direct manifestation of the problem is a phenomenon. Therefore, consistent with the concept of phenomenological teaching, this article proposes project design for STEAM education based on striking or unusual life phenomena; using phenomena to capture children's attention and trigger children's interest in inquiry. It should be emphasized that the word " striking" is added in this article. Striking phenomena means not ordinary, normal or usual, or invisible phenomena. On the contrary, the phenomenon needs to evoke a strong psychological experience and have a certain impact. Such as (1) real and intuitive, striking contrast, and vivid phenomena; (2) marvelous and interesting, unusual, scientific and magical phenomena; (3) contains scientific principles and mechanisms, and can be deeply explored. [10] Of course, these phenomena must also stem from the life of the child or the surrounding life. That is, a phenomenon in the lives of young children, a phenomenon related to themselves and their surroundings. Some phenomena, such as the protective colors of animals (chameleons, etc.), are difficult to observe and come into contact within the lives of young children. As a result, they lack the real situation and direct experience of young children, so they are not typical for young children. While the little ants are busy in a long queue to move back to the food from a distance, running around, and mighty, and sometimes a few ants are in the same pace as a grain of rice... Young children often stop for a long time to watch them. It can arouse children's strong interest and doubts, which is a striking life phenomenon.

\subsection{Micro-project Design Integral Ideas and Structure}

STEAM education emphasizes that the characteristics of real problems and situations naturally coincide with the project learning concept. Meta-analysis shows that overall, project-based learning has a promoting effect on learning. [12] However, for children in preschool, STEAM project activities are different from the exploration of primary and secondary school projects, and can not blindly transplant or copy educational projects or cases in primary and secondary schools. At the same time, even the pre-school STEAM education, it is necessary to fully reflect the essence and characteristics of the STEAM education concept, which is different from the previous structured learning based on abstract themes or comprehensive knowledge learning based on phenomena. Preschool STEAM education has its unique aspects due to the particularity of the learning subject and the particularity of the educational goals.

This article proposes the microprojects based on typical life phenomena, and the overall design ideas are as follows: (1) To capture and catch those striking phenomena around children's lives, and cut in from the striking phenomena. Preschool STEAM education must first start with "striking or typical phenomena"; which is the starting point for STEAM project activities. (2) To mine and dig the key scientific problems behind the phenomenon and the progressive problem chain. Reggio Emilia 's teachers believe that one of the particularly difficult aspects of the teacher 's role is to find challenging and satisfying issues; "For teachers, a difficult task is to help children find a large enough, Difficult problems can allow young children to invest the most energy and think for a long time. "[13] In addition to the above-mentioned search for challenging problems, Reggio 's educational philosophy also points out the knots behind the problems. Understand the exploration space of the problem. For example, not only larger projects must contain a wealth of questions, but even a small stage of daily work should theoretically have a stagnation point, or "knot"... anything problem that will stop children and 
hinder their actions is a cognitive "knot". [13] These key scientific problems are also issues that touch on important scientific principles and mechanisms. Therefore, when digging up problems, list the scientific principles, laws, mechanisms, etc. which are touched or implied. (3) To define the micro-project and make clear the composition of sub-projects. (4) To be aware of and realize the STEAM learning elements contained in the projects. In addition, to clarify the core concepts / interdisciplinary concepts contained in the project, the appropriate age for activities, the relationship with children's life and its expansion, the necessary materials and tools, etc.

In a word, with the help of wonderful and interesting phenomena to establish interdisciplinary links with key scientific issues, to form appropriate project resources for development, to stimulate children's intrinsic interest in continuing active exploration, to conduct hypothesis-testing in-depth inquiry learning.

\section{The Process and Example of a Micro-project Design}

\subsection{Examples of Striking Phenomena Around Children's Own Lives}

Phenomenon 1: There are no two identical leaves in the world, nor two identical people. There are lines on the leaves, and we also have these lines on our fingers. Everyone 's fingerprint is unique, and the fingerprint is considered to be the "identity card of the human body". Scientists pointed out that the probability of the same fingerprint is about one in 15 billion. According to the current population of the earth, the fingerprint is still a reliable identity code for a person.

Phenomenon 2: There are twins in almost every kindergarten. I believe the children must be very puzzled when they meet for the first time: Why do they look so similar? There will also be a lot of jokes because it is impossible to tell who is the elder brother, the younger brother or the older sister. After a period of time, most of the children can distinguish them well. What method do the children use to distinguish?

Phenomenon 3: When children grow up, they often hear such words as "This child and his (her) father (mother) look like a real image" or "This child's temper and his (her) father (mother) It's exactly the same. "What's the matter? I believe that the young children will definitely think, "Why do we look like our parents and not other parents? How did the temper of my parents transfer to me?"

The above phenomena are all biological phenomena, and more specifically, they all belong to genetic, genetic and evolutionary phenomena. Choose a specific phenomenon arbitrarily, such as the texture of children's fingertips-the secret of human inheritance, to design a microproject. This phenomenon is closely related to children's own lives. Every child has his own fingerprint, and every child's fingerprint is different. Corresponding life applications include fingerprint locks (mobile phone), fingerprint passwords, fingerprint resolution cases, and visas to go abroad. Children's understanding of the world begins with knowing their own bodies, but the human body has the most difficult to understand secrets, and the human body's password has not been cracked in depth so far. Therefore, taking the often overlooked "self" as the object of exploration not only roots the life of the child, but also helps to enhance the child's awareness of self-care and self-protection, and helps to stimulate the child's enthusiasm for the exploration of life.

\subsection{Key Scientific Problem and Progressive Problems Behind the Phenomena}

Inheritance and variation are processes that cannot be directly observed, but exist in every living body. It is these influencing factors that have created our unique individuals and biological diversity. Every life is a miracle, and there are many magical manifestations in us. Scientists believe that fingerprints are determined jointly by genetics and the environment. Although no two people in the world will have identical fingerprints, they are still controlled by genetic genes. Fingerprints are close to the lives of young children and are interesting. Studying fingerprints is an effective way for young children to perceive human genetic characteristics.

Key scientific questions: What kind of genetic secrets do fingerprints contain (what are the mechanisms and laws of human inheritance)? Why are there no two identical leaves and no two identical people in the world? Why can you identify a person through these. How much information is hidden in these lines?

Progressive problem chain: What is the external manifestation of inheritance? What are its obvious characteristics? What is the role of genetics? How can we understand mutation, evolution, and degradation? What is the relationship between them?

\subsection{Extractable STEAM Education Micro-project and Its Subprojects}

The progressive problems of micro-project mining mentioned above are not limited. At the same time, these progressive problems should also consider the questions and thoughts of children in the process of inquiry, and what problems they may also emerge. For example, will fingerprints change with age? Can fingerprints really reflect how smart the children are (intelligence quotient)? Can modern cloning technology create exactly the same people and so on. Human's understanding and research of life science begins with the human body and ends with the human body. With the latest technology in life sciences, young children can do preliminary observation, operation experiments, or indirect understanding, laying the foundation for young children to adapt to the era of rapid technological development. 
Table 1. STEAM exploration micro-project and the sub-projects that can be extracted from the texture of the fingertips of young children.

\begin{tabular}{|c|c|c|c|c|}
\hline Micro-project & $\begin{array}{l}\text { The core issue / } \\
\text { Scientific } \\
\text { principles }\end{array}$ & $\begin{array}{l}\text { Progressiveness } \\
\text { Problem chain }\end{array}$ & Sub-projects & The elements of STEAM learning \\
\hline \multirow{5}{*}{$\begin{array}{l}\text { Fingerprints - } \\
\text { The secret of } \\
\text { human genetics }\end{array}$} & \multirow{5}{*}{$\begin{array}{l}\text { What is the } \\
\text { genetic secret } \\
\text { behind the } \\
\text { fingerprint? } \\
\text { What are the } \\
\text { mechanisms and } \\
\text { laws of human } \\
\text { inheritance? }\end{array}$} & $\begin{array}{l}\text { What is the } \\
\text { fingerprint? } \\
\text { Are there different } \\
\text { fingerprints between } \\
\text { children? }\end{array}$ & $\begin{array}{l}\text { 1. Fingerprint or leaf } \\
\text { vein extraction } \\
\text { activities; } \\
\text { 2. Find and compare } \\
\text { children's fingerprint } \\
\text { activities }\end{array}$ & $\begin{array}{l}\text { Science: the texture and differences of fingertips. } \\
\text { Engineering / Technology / Art: Thumb press on seal or colored clay, } \\
\text { magnifying glass magnification / microscope observation / ppt assistance. } \\
\text { Boil / add alkali to separate the mesophyll, extract the veins, dye them with } \\
\text { pigments, print, and dry the bookmarks of homemade veins. } \\
\text { Mathematics: the number and shape of lines. }\end{array}$ \\
\hline & & $\begin{array}{l}\text { Is the fingerprint of the } \\
\text { baby the same as that } \\
\text { of the parents? } \\
\text { (Is genetics completely }\end{array}$ & $\begin{array}{l}\text { Fingerprint activity } \\
\text { of baby parents }\end{array}$ & $\begin{array}{l}\text { Science: What is genetics? Genetic phenomenon. } \\
\text { Engineering / Technology / Art: photos, thumb press on seals or colored } \\
\text { clay, magnifying glass magnification / microscope observation / ppt } \\
\text { assistance. }\end{array}$ \\
\hline & & $\begin{array}{l}\text { Does the baby and } \\
\text { mother look the same? } \\
\text { why? }\end{array}$ & $\begin{array}{l}\text { Baby's parents' } \\
\text { comparison }\end{array}$ & $\begin{array}{l}\text { Mathematics: the number and shape of lines. } \\
\text { Science: Genes and mutations. Similarities and differences between the } \\
\text { characteristics of babies and parents-the universality of inheritance and } \\
\text { variation. Engineering/Technology/Art/Number Study: photographs and } \\
\text { paintings, look for places that are the same as and different from the } \\
\text { looks of your parents; DNA helix structure model, operating to sense the } \\
\text { diversity of gene arrangement For example, young children use } 20 \\
\text { snowflakes of the same number, color and size to line up, and compare } \\
\text { the probabilities of the same arrangement. }\end{array}$ \\
\hline & & & & $\begin{array}{l}\text { Science: ring pattern, vortex pattern, bow pattern, etc. } \\
\text { Mathematics: Count the numbers and record them. }\end{array}$ \\
\hline & & $\begin{array}{l}\text { How is fingerprint } \\
\text { applied to life? }\end{array}$ & $\begin{array}{l}\text { Toddler ID Card } \\
\text { Making Activity }\end{array}$ & $\begin{array}{l}\text { Engineering / Technology / Art: Draw a picture, make a card / fingerprint } \\
\text { film, and recognize it. Pictures / videos, etc., help to introduce the methods } \\
\text { / advanced technologies for detecting and extracting fingerprints by public } \\
\text { security organs. Various "fingerprint recognition" security software, etc. }\end{array}$ \\
\hline
\end{tabular}

\section{Discussion}

In the context of the current lack of high-quality resources and example references for STEAM education practices in Chinese kindergarten, the above project design helps to a certain extent to build a bridge between the STEAM education theory and STEAM education practice; it helps to inspire the practical community to explore and reflect STEAM education Substantive in-depth exploration. Those interesting, problematic, and in-depth STEAM education practice will also help protect and nurture children's natural STEAM learning interest, engagement, and enthusiasm; help develop children's scientific thinking and problem-solving skills. These early learning experiences are an important start to support children's effective STEAM learning in the future; it is a necessary prerequisite to produce a cascading effect that continues to develop with age; and it is also a solid foundation for the emergence of China's future scientific and technological innovation talents.

Numerous scientific researches have shown that the key to whether children can benefit from kindergarten is quality. $[14,15]$ And high-quality early childhood education is an important foundation for shaping STEAM innovative talents. As a result, providing high-quality STEAM education to all children has become a new policy trend in developed countries. [16] Therefore, this article hopes to throw a brick and attract jade to trigger the successive development of STEAM educational microprojects suitable for preschool children to explore. At the same time, anchoring "high quality" to innovate the project design concept of pre-school
STEAM education, thereby developing corresponding projects. Such as the systematic development of representative project resources in major scientific fields (such as life science, physical science, earth and space science, environment and ecological science, engineering and technology, etc.). This clarifies the vagueness and misunderstanding of society, family and gardens about pre-school STEAM education; meets the needs of resource use and reference in kindergartens, early education and training institutions, family education, education management departments, etc.; guides our country's pre-school STEAM education to gradually rise Quality track.

In addition, Wang (2019) found that STEAM activities are conducive to the development of multiple intelligences in 4-5 years old classroom,[17] but currently research from this perspective is very scarce, such as lack of empirical research on the potential of STEAM education. [18, 19] The examination of STEAM education learning results will also have an important impact on the development of effective STEAM education projects or models. [19] Therefore, future research is necessary to strengthen empirical research to clarify the actual effect of pre-school STEAM education. From this perspective, the effectiveness of the preschool STEAM education projects is provided; at the same time, it provides a strong evidence reference for the decision-making of preschool STEAM education policies.

This article was supported by the grant of Teaching Reform and Research from Suzhou University of Science and Technology, namely "The Research and Practice to Develop Preschool STEAM Education Professionals Based on the Coaching Model" (2019JGMJ-05). 


\section{References}

[1] Yakman, G. STEAM Education: an overview of creating a mode of integrative education. Pupils Attitudes Towards Technology 2008 Annual Proceedings. Netherlands, 2008.

[2] Tippett, C. D., Milford, T. M. Findings from a Pre-kindergarten Classroom: Making the Case for STEM in Early Childhood Education [J]. International Journal of Science and Math Education, 2017, 15: S67-S86.

[3] DeJarnette, N. K. Implementing STEAM in the Early Childhood Classroom [J]. European Journal of STEM Education [J]. 2018, 3 (3), 18-27.

[4] Wang, Wei., Yuan, Lei. Research on the teaching model of the STEAM curriculum based on the project in the connection stage of the young and the primary [J]. Modern Distance Education, 2018 (3): 51-58.

[5] Hu, Hui-rui, Wang, Yang., Chen, Xiao-ling. Kindergarten STEAM Activities Design and Implementation from a Perspective of Design Thinking [J]. Journal of Sha anxi Xueqian Normal University, 2019, 35 (8): 63-67.

[6] Kim, D., Bolger, M. Analysis of Korean Elementary Pre-Service Teachers' Changing Attitudes About Integrated STEAM Pedagogy Through Developing Lesson Plans [J]. International Journal of Science and Math Education, 2017, 15: 587-605.

[7] Zheng, Wei. China STEAM Education Development Report [M]. Science Press, 2017.

[8] Zhang, Mo., Wang, Wei., Yuan, Lei. Research on Activity Design of STEAM Education in Kindergarten [J]. Modern Distance Education, 2018 (4): 76-80.

[9] Li, Xue-shu, Fan, Guo-rui. Reform Strategies of Kindergarten Science Education Based on STEAM [J]. Education Science, 2020, 36 (1): 82-90.

[10] Peng, Du-hong. An Analysis of the Key Goals and
High-quality Teaching Model of STEAM Education in Preschool [J]. Journal of Suzhou University of Science and Technology (Social Science), 2019, 36 (5): 93-100.

[11] Yu Guowen, Cao Yiming. Interdisciplinary Teaching Research: Taking Finnish Phenomenon Teaching as an Example [J]. Foreign Primary and Secondary Education, 2017 (7): 57-60.

[12] Zhang Wenlan, $\mathrm{Hu}$ Jiao. Has the learning effect of project-based learning happened?_-A meta-analysis based on 46 experimental and quasi-experimental studies [J]. Audio-visual Education Research, 2019 (2): 95-104.

[13] Caroline Edwards, Laila Gandini, George Foreman, Luo Yafen, with English, translated by Jin Naiqi. One hundred languages for children [M]. Nanjing Normal University Press, 200612 First edition of the month.

[14] Lipsey, M. W., Farran, D. C., Durkin, K. Effects of the Tennessee Prekindergarten Program on children's achievement and behavior through third grade [J]. Early Childhood Research Quarterly, 2018, 45: 155-176.

[15] Currie, J., \& Thomas, D. School quality and the longer-term effects of Head Start [J]. Journal of Human Resources, 2000, 35 (4), 755-774.

[16] Early Childhood STEM Working Group. Early STEM Matters: Providing High-Quality STEM Experiences for All Young Learners [R]. Erikson Institute and UChicago STEM Education, Report, 2017, January.

[17] Wang, Xin. A practical study on the effect of STEAM teaching activities in kindergarten middle class on children 's multiple intelligences [D]. The 2019 Master of Education degree thesis of preschool education major of Shanghai Normal University, instructor: Huang Lian.

[18] Land, M. H. Full STEAM Ahead: The Benefits of Integrating the Arts Into STEM [J]. Procedia Computer Science, 2013, 20, 547-552.

[19] Perignat, E., Katz-Buonincontro, J. STEAM in practice and research: An integrative literature review [J]. Thinking Skills and Creativity, 2019, 31: 31-43. 